\title{
(4R
}

\section{Review of Traumatic Asphyxia Syndrome with a Case Presentation}

\author{
Travmatik Asfiksi Sendromunu Olgu Sunum Ile Gözden Geçirme
}

Illyas Ertok, Gülhan Kurtoğlu Çelik, Güllü Ercan Haydar, Onur Karakayalı, Mehmet Yılmaz, Teoman Erşen

Department of Emergency Medicine, Ankara Atatürk Training and Research Hospital Ankara, Turkey

\section{ABSTRACT}

Traumatic asphyxia is a rare syndrome in which the thoracoabdominal region is exposed to pressure and it presents with cervicofacial cyanosis and oedema, subconjunctival haemorrhage, and petechial haemorrhage in the face, neck and upper part of chest. In this report we present a 28 year old male patient whose whole body except the head and neck stayed under soil for about 30 minutes as an example case in order to review traumatic asphyxia syndrome.

Keywords: Trauma, asphyxia, cervicofacial cyanosis Received: 30.03.2012 Accepted: 17.07.2012

\section{ÖZET}

Travmatik asfiksi servikofasiyal siyanoz ve ödem, subkonjuktival hemoraji ve peteşiyal hemorajinin yüz, boyun ve göğüs üst kısmında görüldüğü torakoabdominal bölgenin baskı tarzında güce maruz kaldığı nadir görülen bir durumdur. Biz burada başı ve boynu hariç diğer tüm vücudu yaklaşık 30 dk kadar toprak altında kalan olguyu travmatik asfiksi sendromunu gözden geçirmek amacıyla sunmak istedik.

Anahtar Kelimeler: Travma, asfiksi, servikofasiyal siyanoz Geliş Tarihi: 30.03.2012 Kabul Tarihi: 17.07.2012

\section{Introduction}

Traumatic asphyxia is a rare syndrome in which the thoraco-abdominal region is exposed to pressure and it presents with cervicofacial cyanosis and oedema, subconjunctival haemorrhage, and petechial haemorrhage in the face, neck and upper part of chest (1). Traumatic asphyxia syndrome is caused by excessive elevation in venous pressure due to severe blunt chest trauma and is also called acute thoracic compression syndrome (2). It is a rare syndrome which was first defined by Oliver d'Angers in 1837 in autopsy studies. It is also referred as Oliver's syndrome or Perth's syndrome or ecchymotic mask (3). Symptoms develop as a result of deep inspiration, closure of the glottis and increasing thoracic pressure. Characteristic findings are petechiae of the upper part of the face and chest, subconjunctival haemorrhage, cervical cyanosis, loss of vision and neurological symptoms due to cerebral haemorrhage and oedema which range from mild symptoms to coma (2-4). It is a rare syndrome and the incidence is not clearly known. It may be life threatening depending on the severity and duration of injury.

\section{Case Report}

A 28 year old man who had been crushed by soil while working was brought to our emergency department. He explained that with the exception of his head and neck, his entire body stayed under the soil for about 30 minutes. The patient was confused and the Glasgow Coma Scale (GCS) was E4 M6 V4. His vital signs were as follows: blood pressure: 128/82, pulse: 99 beats/min, respiratory rate: 26 breaths/min, and $\mathrm{SpO}_{2}: 90-92 \%$. There were diffuse petechiae and echymoses on the neck and face, bilateral subconjunctival haemorrhage, and bilateral orbital bruising and exophthalmos (Figure 1-3). The patient was tachypnoeic, breath sounds had decreased and there were petechial lesions on the upper part of the chest wall and tenderness to palpation in the right chest wall. In the abdominal examination there was no rebound and defense. Fundus examination showed that pupillaries were isocoric, light reflex was bilaterally positive, and the optic disc and retina were natural in appearance. Other system examinations were normal. 


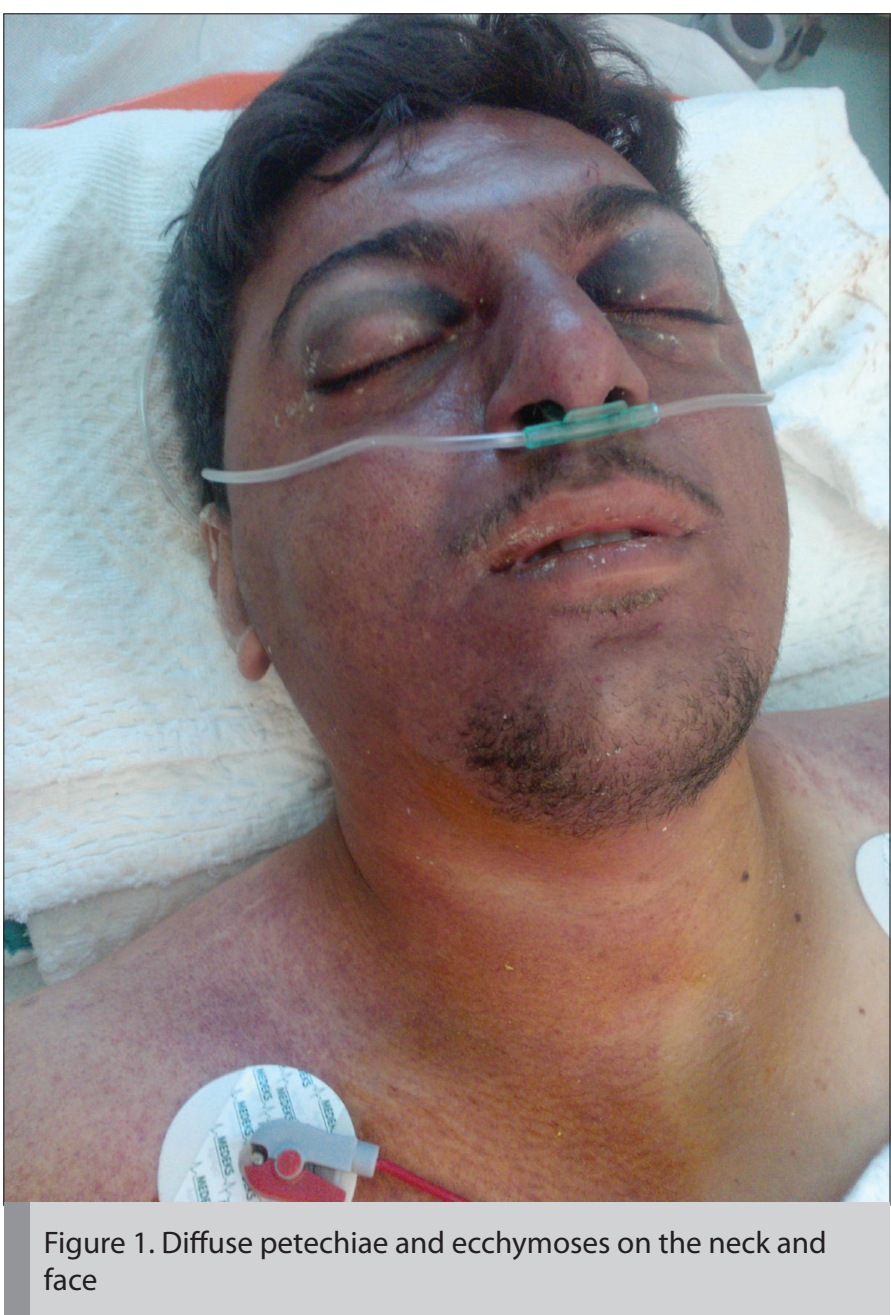

The laboratory results were normal except for liver function tests: aspartate transaminase (AST): 89 (0-40 U/L), and alanine aminotransferase (ALT): 110 (0-41 U/L). Abdominal ultrasound, brain and cervical tomography and echocardiography were normal. There were minimally displaced fractures at the level of the right front costachondral joints of the second, third and fourth ribs, pneumothorax up to $9 \mathrm{~mm}$, and contusion in the middle lobe segments of the right lung on the chest X-ray and the CT scan of the thorax. Thoracostomy and closed underwater drainage were performed the right hemithorax due to respiratory distress. After this, oxygen saturation increased to $98-100 \%$ and the patient was followed in the emergency department. Although the vital signs were normal at the $12^{\text {th }}$ hour of follow-up, control abdominal ultrasonography was performed because the control haemoglobin was decreased from 16.0 to $14.0 \mathrm{~g} / \mathrm{dL}$. However, control abdominal ultrasound was normal so contrast-enhanced abdominal tomography was performed and no intra-abdominal pathology was detected. In the abdominal computed tomography an oblique fracture on the left wing of the anterior sacral vertebra and fracture lines on the left transverse processes of the L2-3 vertebrae were observed. Vital signs and laboratory findings were normal in further follow-up. The control chest X-ray was normal on the sixth day and the patient was discharged. The consent was obtained from the patient regarding the use of photographs.

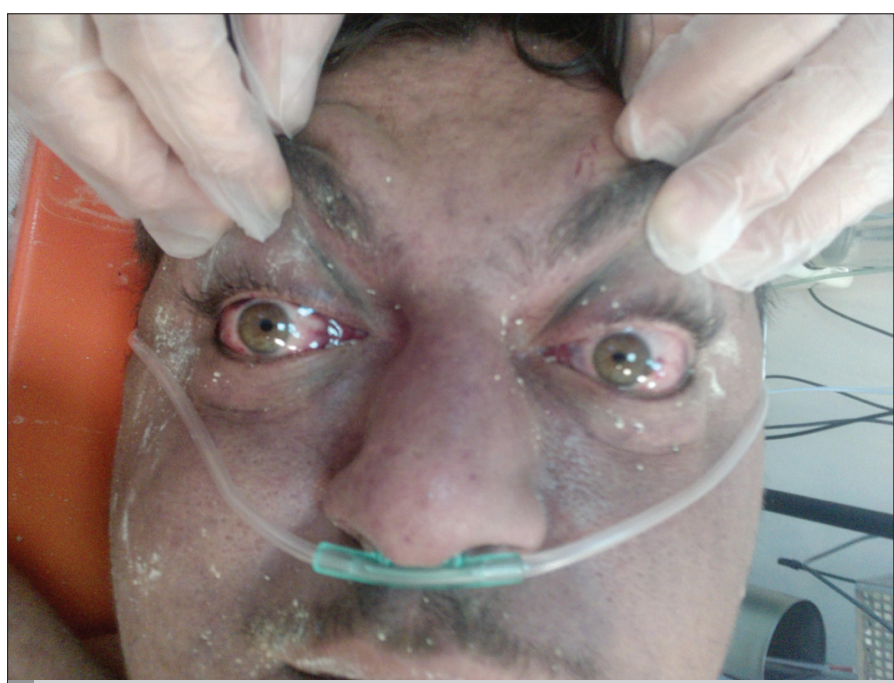

Figure 2. Bilateral subconjunctival haemorrhage



Figure 3. Bilateral orbital bruising and exophthalmos

\section{Discussion}

Although traumatic asphyxia develops due to sudden, severe, compressive blunt trauma to the chest or upper abdomen, it may also occur due to a prolonged Valsalva manoeuvre secondary to severe vomiting and coughing, or epileptic or asthmatic attacks, without outer compression. It is a rare syndrome but the incidence is not clearly known $(4,5)$. The first explanation for the development of the syndrome was made by Tardieu in 1866. "The resistance against drowning causes spot like ecchymosis on the face, neck and chest wall." (6). Although the pathophysiological mechanism of traumatic asphyxia is not completely known, acute compression to the mediastinum, thorax and heart is commonly thought to be the cause. This condition is caused by orientation of blood to the cervicofascial area due to deep inspiration upon realising the accident, closed glottis and elevation of thoracoabdominal pressure. This condition does not occur in patients who do not realise that the accident has occurred (7) 
Increased intrathoracic pressure is transmitted to the superior and inferior vena cava, mediastinal veins and right atrium. After this, the blood fills to valveless veins in the neck and head by the effect of pressure (retrograde flow). The sudden increase in the pressure in the large veins is transmitted to the cervicofacial veins and then to the small venules and capillaries. Because cervicofacial veins don't have a valve system which prevents transmission of pressure, the pressure is directly transmitted to small venules and ruptures occur in the vessels. Traumatic asphyxia occurs only at the regions which are drained by the valveless veins. In the typical clinical presentation, cyanotic haemorrhagic lesions in head and neck, scleral and subconjunctival haemorrhage, and petechial haemorrhages in the cranio-cervical region are seen as a result $(3,7,8)$.

Cervical venous drainage is provided by internal and external jugular veins. Structures such as the brain, larynx, trachea and oropharynx drain into the internal jugular vein; the subcutaneous tissues in in the neck and scalp drain into the external jugular vein. The external jugular vein has two pairs of valves and these valves cannot prevent back flow. On the contrary, the internal jugular vein valves prevent this repeated back flow. This explains why the superficial cervical tissues and scalp may be more affected than the brain and respiratory tract in traumatic asphyxia. However, if the pressure increases higher than $45 \mathrm{mmHg}$ these valves may be insufficient (9).

Clinical presentation of acute thoracic compression depends on the duration and severity of compression on the thorax. Symptoms are commonly seen on the skin, eyes, brain, nose, airways, chest, gastrointestinal tract, and abdominal region. Deep cyanosis may develop and petechiae and subcutaneous haemorrhage may occur concurrently. Cyanosis may be seen in the head, neck and upper chest (craniocervical cyanosis), whereas it is usually not seen in the arms and legs. Lower parts of the body are protected against the increased venous pressure by the valves. Alternatively, increased airway pressure may be compressing the inferior vena cava in order to protect the lower part of the body $(10,11)$.

Petechiae may be seen in the tongue, lips, mouth and pharynx. Ophthalmic haemorrhage is often seen in the subconjunctival region, but it may also be seen in the retina vitreous and optic nerve. In this case, blindness may occur which may resolve within a few days or may sometimes be permanent. Exophthalmi may be seen due to bleeding behind the eye globes. Bilateral optic disc oedema cases have been reported in the literature (12). In the clinical course, symptoms ranging from mild to coma may develop due to brain haemorrhage and oedema. Neurological sequelae include loss of consciousness, disorientation, agitation and spinal cord injury. On the other hand, paraplegia or tetraplegia may be seen without neurologic injury. These symptoms are thought to be due to hypoxic injury such as cerebral oedema and haemorrhage (13).

Symptoms associated with the chest such as flail chest, rib fracture and lung contusion may also occur, but it is possible that no chest pathology is seen. As a result of an equal increase in intravascular, interstitial and alveolar pressures due to chest compression, the pressure gradient does not change and hydrostatic pulmonary oedema does not develop, although direct lung injury and oedema may occur as a result of trauma $(3,4)$. Cardiac injury may occur in many cases. A detailed cardiac examination should be performed to ensure that this possibility is not overlooked. Progression of venous pressure to the abdominal organs may result in haematemesis, intestinal mucosa bleeding and haematuria (13). The development of sequelae depends on the duration and severity of the crush injury. Prolonged compression may be life threatening due to apnoea and hypoxaemia and may increase mortality (14). Although the prognosis is good in patients with mild symptoms, it has been reported that severe shock, cerebral anoxia, neurological sequelae and even sudden death within a few minutes may occur as a result of prolonged thoracic compression $(15,16)$. Morbidity and mortality are usually associated with the presence and severity of pulmonary and neurologic injury $(1,3,5,8,17)$.

The mainstay of treatment is supportive treatment. The patient should be monitored, oxygen saturation and arterial blood gas analysis should be followed, and oxygen supplementation should be obtained (8). Intracranial pressure monitoring may be considered because cerebral oedema may also occur. The head of the bed should be raised by $30^{\circ}$ and oxygen therapy should be given in order to reduce intracranial pressure (1). It has been reported that even patients with neurological symptoms due to brain oedema have recovered within one to two weeks with supportive treatment (18).

\section{Conclusion}

Traumatic asphyxia is a rare syndrome which has a good prognosis and should be considered carefully. Supportive therapy and raising the head of the bed by approximately $30^{\circ}$ may be sufficient in the management of the sydrome, but as in our case, in the presence of additional injuries, further treatments oriented towards specific damage such as tube thoracostomy should be applied.

\section{Conflict of interest}

No conflict of interest was declared by the authors.

\section{References}

1. Eken $C$, Yigit $O$. Traumatic asphyxia: a rare syndrome in trauma patients. Int J Emerg Med 2009; 2: 255-6. [Crossref]

2. Guitron J, Huffman LC, Howington JA, LoCicero III J. Blunt and Penetrating Injuries of the Chest Wall, Pleura, and Lung. In: Shields TW, Locicero III J, Reed CE, Feins RH, eds. General Thoracic Surgery. 7th ed. Philadelphia: Lippincott Williams and Wilkins; 2009: 891-902.

3. Şenoglu N, Oksuz H, Zıncırcı B, Ezbercı M, Yasım A. Severe traumatic asphyxia: two case report and literature review. Turkish Journal of Thoracic and Cardiovascular Surgery 2006; 14: 78-81.

4. Ibarra P, Capan LM, Wahlander S, Sutin KM. Difficult airway airway management in a patient with traumatic asphyxia. Anesth Analg 1997; 85 216-8. [Crossref]

5. Dunne JR, Shaked G, Golocovsky M. Traumatic asphyxia: an indicator of potentially severe injury in trauma. Injury 1996; 27: 746-9. [Crossref]

6. Williams JS, Minken SL, Adams JT. Traumatic asphyxia-reappraised. Ann Surg 1996; 167: 384-92. [Crossref]

7. Kilıcgun A. Journal of Clinical and Analytical Medicine 2010; 361

8. Lee MC, Wong SS, Chu JJ, Chang JP, Lin PJ, Shieh MJ, et al. Traumatic asphyxia. Ann Thorac Surg 1991; 51: 86-8. [Crossref] 
9. Imai M, Hanaoka Y, Kemmotsu O. Valve injury: a new complication of internal jugular vein cannulation. Anesth Analg 1994; 78: 1041-6.

10. Nishiyama T, Hanaoka K. A traumatic asphyxia in a child. Can J Anaesth 2000; 47: 1099-102. [Crossref]

11. Karamustafaoglu YA, Yavasman I, Tiryaki S, Yoruk Y. Traumatic asphyxia. Int J Emerg Med 2010; 3: 379-80. [Crossref]

12. Esme H, Solak O, Yurumez Y, Ermis S, Yaman M, Fidan F. Perthes syndrome associated with bilateral optic disc edema. Can J Ophthalmol 2006; 41: 780-2. [Crossref]

13. Sandiford JA, Sickler D. Traumatic asphyxia with severe neurological sequelae. J Trauma 1974; 14: 805-10. [Crossref]
14. Hurtado TR, Della-Giustina DA. Traumatic asphyxia in a 6- year-old boy. Pediatr Emerg Care 2003; 19: 167-8. [Crossref]

15. Barakat M, Belkhadir ZH, Belkrezia R, Faroudy M, Ababou A, Lazreq C, et al. Traumatic asphyxia or Perthe's syndrome. Six case reports. Ann Fr Anesth Reanim 2004; 23: 59-62. [Crossref]

16. Jongewaard WR, Cogbill TH, Landercasper J. Neurologic consequences of traumatic asphyxia. J Trauma 1992; 32: 28-31. [Crossref]

17. Sarıhan H, Abes M, Akyazıcı R, Cay A, Imamoglu M, Tasdelen I, et al. Traumatic asphyxia in children. J Cardiovasc Surg (Torino) 1997; 38: 93-5.

18. Cobanoglu U, Yalcınkaya I. Torasic ınjurıes. Journal of Emergency Surgery 2010: 16: 77-83. 